\title{
Den historiske drejning
}

\begin{abstract}
Politologien, ikke mindst disciplinen intemational politik, bygger for en stor del på historisk forskning. Blandt nyere bidrag til studiet af international politik finder man en del "verdenshistorier" analyser af, hvordan interaktionen mellem de politiske systemer har udviklet sig op gennem historien. Den engelske skole er stærkt repræsenteret inden for denne "historiske drejning". Men også neorealismen gør sig galdende. Som nyorientering inden for international politik er den historiske drejning mere frugtbar end den stærkt opreklamerede sproglige drejning.
\end{abstract}

Mange politologer ringeagter historikere og historie som et fag, der "ikke kan se skoven for bare træer". Megen historisk forskning og historieskrivning retter sig mod at rekonstruere begivenheder og hændelsesforløb i fortiden på grundlag af et minutiøst arbejde med kildematerialer og bruger ikke synderlig plads på generelle teori- og metodebetragtninger. For mange politologer er det ensbetydende med en rent deskriptiv, idiografisk ${ }^{1}$ blindgyde - historikere mikroanalyserer det enkelte træ, men făr aldrig sanset skoven, siger politologerne. Derfor lægger politologer så megen vægt på teoridannelse. Deres videnskabsideal er den generaliserende, nomotetiske samfundsvidenskab, i sig selv en relevant faglig ambition.

Men i den forbindelse glemmer mange politologer, at deres fag er storforbruger af historikeres empiriske forskning. Såvel komparativ politik som international politik, ja alle fagets discipliner ville være dybt enfoldige, hvis ikke historievidenskaben, herunder idehistorien, havde givet dem et historisk perspektiv på analysens genstand. Stat, klasser og magt kan ikke anskues løsrevet fra tid og rum. Mange af statskundskabens klassikere er makrohistoriske synteser - tag bare Barrington Moore (1966), hvad komparativ politik angår. Inden for sociologi findes tilsvarende en historieorienteret makrosociologi, som nogle lærebøger i international politik inkluderer i disciplinen international politik (Smith, 1997; Mann, 1986, 1993; Tilly, 1992).

De to sidstnæunte forfattere kan sammen med visse andre tages til indtægt for "en historisk drejning" inden for studiet af international politik parallelt til den "sproglige drejning", 2 der er nok så opreklameret (Cox, Dunne og Booth, 2001). Der er kommet en ny underskov af diakrone ${ }^{3}$ analyser af, hvad der driver samkvemmet mellem politiske systemer - historiske perspektiver på den internationale politiks aktører og på kernebegrebet det internationale system. Det er eksempler på denne nyorientering, der er emnet for denne forskningsoversigt. Først gives en introduktion til den historiske drejning $i$ lyset af faget international politiks metodedebatter og den såkaldte engelske skoles ${ }^{4}$ genkomst. Dernæst præsenteres nogle eksempler på nye verdenshistorier skrevet med faget international politik som pennefører. Med det menes fremstillinger, der ser på interaktionen mellem de højst forskelligartede politiske systemer, der har eksisteret op gennem historien, altså verdenshistorier, der anlægger et systemisk og politologisk fugleperspektiv på historien. Først drøftes Adam Watson (1992), derpå Buzan og Little (2000) 
som eksempler på bidrag, der helt eller overvejende bygger på den engelske skoles syn på international politik. Som eksempler på alternative bidrag til den historiske drejning af lige så stor faglig vægt præsenteres Paul Kennedy (1988). Sluttelig gives eksempler på danske populariserende bidrag til den historiske drejning. Artiklen har som overordnet budskab, at der er flere vitaminer for faget international politik, ja for hele samfundsvidenskaben at hente i bølgen af historie, end der er i den sproglige drejning.

Som appetitvækker kan det nævnes, at virkelighedens internationale politik, dvs. på den ene side globaliseringens verdensomspændende fragmentering af etablerede strukturer og på den anden side magtkoncentrationen omkring USA som følge af den kolde krigs ophør har skabt en hel industri af litteratur om imperier. Såvel kritikere af USA som globaliseringskritikere søger hermed tilflugt i et af verdenshistoriens begreber for grænseoverskridende magt for at indkredse problemstillingen (Hardt og Negri, 2004; Johnson, 2004). Nok så tankevækkende er der dem, der efterlyser mere imperium som svar på de problemer, som globaliseringen skaber, uden af den grund at give køb på kritikken af nutidens USA (Lal, 2004).

\section{Den historiske drejning i international politik før og nu}

Selv om de første lærebøger i international politik var præget af ikke-politologiske fag som jura, blev studiet af international politik ligesom resten af politologien på et tidligt tidspunkt domineret af amerikanske forskere og deres banebrydende dataindsamlingsmetoder og positivistiske holdninger, dengang kaldet behavioralisme. ${ }^{5}$ Det gav afsæt for faget international politiks såkaldte anden og efter manges mening vigtigste debat, nemlig debatten mellem behavioralister og raditionalister omkring 1970 (Jackson og Sørensen, 1999: 45-48, 55-56, 218228). Det var første gang, at den historie- og folkeretsinspirerede engelske skole i skikkelse af Hedley Bull (1969) gik i offensiven i et fors $\emptyset \mathrm{g}$ på at sætte dagsordenen for studiet af international politik. Bull afviste (ligesom C.A.W. Manning) behavioralisternes vision om en rendyrket nomotetisk (se note 1) samfundsvidenskab som håbløs givet den menneskeskabte og -orienterede genstand for studiet. Samfundsforskning indebærer videnskabelig dømmekraft (scholarly judgment), forståelse og indlevelse, ikke naturvidenskabelige årsagsforklaringer, insisterede Bull i debatten mellem ham og systemanalytikeren Morton Kaplan.

Bull udtalte sig på baggrund af den grundforskning, som han sammen med kollegerne i the British Committtee on the Theory of International Relations havde indledt i 1959 - folk som C.A.W. Manning, Martin Wight, Adam Watson. Deres videnskabsteoretiske standpunkt var at integrere filosofi, historie, folkeret og diplomatiske studier i faget international politik. Efterhånden udskrystalliseredes det i en selvstændig retning, der går under betegnelser som international society, historisk institutionalisme, grotianisme, rationalisme eller som her den engelske skole. Skolen anerkender, at der ikke er nogen verdensregering, hvorfor international politik fungerer under anarkiske vilkår med krige som et væsentligt træk. Men det betyder ikke, at realismen med dens pessimistiske magt- og konfliktbetonede synsmåde holder stik. Tværtimod har samkvemmet mellem bystater, 
imperier og i moderne tid stater fremelsket spilleregler, normer og elementer af orden. Følgelig er det mere dækkende at tale om et intemationalt samfund end blot et internationalt system som begreb for det verdensomspændende politiske univers. Systembegrebet forudsætter nemlig ikke på samme måde som samfundsbegrebet et islæt af fælles interesser og værdier (Bull, 1977: 9-14).

I tillæg til den klassiske realismes fokus på (kortsigtet) statsræson som logik bag staters adfærd opererer Watson $(1992: 9,14,240)$ derfor med systemrason, dvs. staternes langsigtede interesse i stabilitet og forudsigelighed som et ledemotiv, der gør staterne mere hensyntagende og moderate i deres adfærd, end man skulle tro. Parallelt med det betoner Amold Wolfers (1962: 72-73) såvel staters nationalegoistiske besiddelsesmål som deres mere fremsynede miljømål - dvs. bestræbelser på at skabe gunstige generelle vilkår for stater, for eksempel oprettelse af internationale organisationer til at tage sig af opgaver, som overstiger den enkelte stats formåen. Hvor meget den enkelte stat i praksis lader sig styre af besiddelsesmål/statsræson eller miljømål/systemræson, er et empirisk spørgsmål (Skak, 2000). Der ligger heri en klar inspiration fra oplysningstidens rationalisme, eksempelvis John Locke samt hans forgænger Hugo Grotius, folkerettens grundlægger (Knutsen, 1997: 254). Argumentet for systemræson/miljømål er det samme som de neoliberale teser om "absolutte gevinster", "fremtidens skygge" og lignende samarbejdsbefordrende mekanismer i forholdet mellem stater.

Faktisk understreger Bull, Wight og andre pionerer inden for den engelske skole, at man end ikke kan udelukke altruistiske træk i international politik. De mener, at der gør sig et universalistisk og humanistisk retfærdighedsaspekt gældende, og fører det tilbage til oplysningsfilosoffen Immanuel Kant i tillæg til ordens- samt konfliktaspektet af international politik. Forfattere som Robert Jackson (1995; Jackson og Sørensen, 1999: 158-165) fremhæver derfor den enkelte statsmands udenrigspolitiske situation som et dilemma, en ofte vanskelig afvejning af tre fuldt ud legitime politiske hensyn:

- varetagelsen af den nationale interesse på vegne af staten

- varetagelsen af statssamfundets kollektive interesse $\mathrm{i}$ orden

- varetagelsen af menneskerettigheder på vegne af individer.

Ophøjet til teori om det samlede internationale system betyder denne treklang af modstridende hensyn, at der i virkeligheden er tre sfarer af international politik: dels en interstatslig systemisk sfære præget af statsræson, magtstræb og militær konflikt - alt det, som realismen med rette peger på; dels en samfundssfære præget af folkeretlig regulering, diplomati og ikke-militære instrumenter; dels en ikkestatslig verdenssamfundssfære præget af hensynet til menneskeheden og i sidste instans individet, hvor miljø og $\varnothing$ konomi kommer ind i billedet (Bull, 1977: 84ff.; Buzan og Little, 2000: 45-47, 104-105, 440). De enkelte sfærers indbyrdes vægt er et empirisk spørgsmål, der afhænger af tid og sted. Helt indlysende er den kantianske verdenssamfundssfære indtil videre den svageste dimension, når man betragter verden og historien som helhed, men tiden efter den kolde krig har ikke været uden fremskridt, eksempelvis humanitære interventioner (Knudsen, 1999). 
På den baggrund er det ikke så overraskende, at den engelske skole havde svært ved at få fodfæste og nå bredere ud i den kolde krigs fase. International politiks anden debat endte med et nederlag til Bulls position til fordel for især den efterfølgende neorealisme, som Kenneth Waltz (1979) var ophavsmand til. Omvendt blev neorealismen bragt til tælling af den kolde krigs ophør og befinder sig nu i en fase af drastiske omformuleringer med teser om civilisationskonflikt, unipolaritet samt en tilbagevenden til udenrigspolitisk teori og deslige (Wivel, 2002). Den engelske skole, derimod, er inde i en renæssance som et magnetfelt for nordeuropæisk forskning $\mathrm{i}$ ikke bare historiens, men også nutidens internationale politiske praksis og folkeretlige problemstillinger (eksempelvis FN, Danmark og verden, 1999; Knudsen, 1999).

Den engelske skoles inspiration fra hermeneutisk ${ }^{6}$ og idiografisk orienterede samfundsvidenskaber som historie betyder, at retningen kan fremstå noget uhåndgribelig som teori betragtet. Man leder forgæves efter falsificerbare hypoteser og klare operationaliseringer med henblik på årsagsforklaringer - hele den systematik og stringens, som er kendetegnede for amerikansk inspireret politologi. Inden for den engelske skole "forklarer" man typisk ved at beskrive et givet fænomens for eksempel statens eller suverænitetens - gradvise opståen og udvikling over tid. Med andre ord det, man inden for metodelæren kalder genetisk forklaring (Rasmussen, 1968: 26). Man kan kalde den engelske skole for induktiv og praksisorienteret, hvorimod dens modparter repræsenterer deduktiv (teoriafledt) politologi. Som læser skal man derfor være forberedt på en ret diskret, kompleks og empirisk argumentation, hvor kun markører som begrebet det internationale samfund afslører forfatterens ståsted. Nogle nyere bidrag har dog en mere direkte, amerikansk facon (Buzan og Litlle, 2000).

I snæver forstand skal man ved denne artikels historiske drejning med afsæt i den engelske skole forstå bidrag som for eksempel Cox, Dunne og Booth (2001), Watson (1992), Knutsen (1997), Osiander (1994) og sidst, men ikke mindst Buzan og Little (2000). Udtrykket the "tum" to history finder man i antologien redigeret af Michael Cox, Tim Dunne og Ken Booth (2001). De lægger afstand til den ahistoriske amerikanske litteratur om international politik på grund af koblingen mellem historie og international politik som fag og som empirisk virkelighed. Hverken hegemonisk stabilitetsteori ellertesen om den demokratiske fred var mulige uden historisk forankring, og i Jugoslavien vakte ophøret af den kolde krig "historien" til live på grusom vis. I stedet for det vante pensum ser antologien på, hvordan fortidens kulturer og ikke-europæiske kontinenter håndterede ordensproblemet og gør endvidere op med myten om den suveræne stat som produkt af den westfalske fred af 1648 (Cox, Dunne og Booth, 2001). Nordmanden Torbjøm L. Knutsen (1997) leverer en grundig gennemgang af tænkningen om international politik sammenholdt med udviklingen i virkelighedens internationale politik op gennem historien - sidstnævnte udgør en lille, ikke ueffen Europahistorie! Andreas Osiander (1994) begrænser sig til den westfalske epoke, 1640 til 1990, men hævder, at det ikke er konflikterne mellem staterne som sådan, men graden af konsensus om de bærende principper for deres indbyrdes forhold, der har præget international politik op gennem historien. Watson (1992) samt Buzan og Little (2000) er taget ud til 
nærmere omtale nedenfor, fordi de er eksempler på hele verdenshistorier set med international politiks øjne.

\section{Adam Watsons verdenshistorie}

Watson (1992) bruger en del plads på tiden før 1648 for at demonstrere, at systemet med suveræne stater historisk set ikke har været den fremherskende struktur. Han indleder sin komparativt anlagte verdenshistorie med at præsentere mulige verdensordener spændende fra uafhængige stater - med magt over ikke kun indre, men også de ydre, sikkerhedspolitiske forhold - til imperiet, det direkte styre af geografisk forskellige politiske enheder fra et enkelt magtcentrum. Imellem de to yderpunkter opregner han nogle mellemformer, og allerede denne gradbøjning af suverænitet eller mangel på samme udfordrer neorealismens tænkning i absolutter. Karakteristisk for den engelske skole lægger Watson vægt på immaterielle sider af international politik såsom legitimitet, et begreb han bruger til at indkredse forskellen mellem eksempelvis Assyriens og Perserrigets praksis som imperier. For at vise dynamikken i fortidens intemationale samfund springer han faraonemes Egypten over som et ret statisk imperium til fordel for Sumer $(3.500$ f.Kr.). Sumereme ikke bare opfandt skriften, men foregreb også nutidens internationale samfund med deres interagerende bystater, hvoraf en, men ikke altid den samme, var lederen - en forløber for EU's roterende formandskaber! Over tid finder man $i$ oldtiden en generel tendens til hegemoni samt moderation fra de konsoliderede imperiers side (Watson, 1992: 123, 126). Ofte overtog erobreme fra randområderne de erobredes institutioner og innovationer (Watson, 1992: 128f.). Stik modsat Waltz (1979) konkluderer Watson, at balancepunktet i international politik hverken er anarki eller hierarki, men den bløde mellemvare (Watson, 1992: 131).

Watsons analyse af det europæiske internationale samfund begynder med middelalderen og fremhæver Europas originalitet i forhold til den imperiale arv fra Rom, Byzans og det muslimske kalifat. Selve middelalderen var diffus og falder uden for Watsons begreber, men havde kristendommen som ramme (1992: 151, note 6). Jura var meget nærværende for den tids sekulære fyrster, da de var afskåret fra at henvise til nationalinteressen som begrundelse for krig (1992: 146f.). Men stater og kongemagt begyndte at tage form og fik hjælp til konsolideringen fra Reformationen (1992: 169). Ironisk nok blev det den katolskekardinal Richelieu, der personificerede statsræson, alliancen mellem Frankrig og de protestantiske magter Danmark og Sverige under Trediveårskrigen (1992: 184). Watsons pendant til oldtidens rastløse randstater (marcher states/marcher communities) er Spanien og Portugal, som vendte energien udad, efterfulgt af andre ekspansionslystne stormagter samt den centraleuropæiske del af Habsburgriget (nutidens Østrig), oprindelig en stødpude i forhold til det dynamiske Osmannerrige (1992: 194f.). På det europæiske kontinent var det Frankrig, der trak det længste strå som ordensmagt indtil landet under Napoleon endte som hegemon - og taber.

Det spændende er det kollektive hegemoni, som dette udfald skabte: den hundrede år lange europaiske koncert 1814-1914 som Watson ser det - en periode præget af systemræson (Watson, 1992: 240-250). Watsons empiriske analyse rum- 
mer således mange flere lag end anarkiet og eksistenskampen mellem de suveræne stater. Den europæiske dynamik var ofte grusom mod de ikke-europæiske egne af verden, men Watson fastholder, at kolonialismen ligesom andre imperier havde sine positive sider (1992: 262). Slutstenen i udviklingen er det europæiske internationale samfunds udstrækning til resten af verden gennem afkolonisering samt FN-pagtens ligestilling af staterne (Generalforsamlingen) og institutionalisering af stormagtskoncerten (Sikkerhedsrådet). Bogen slutter med et spark til den herskende visdom på bjerget:

\begin{abstract}
"The gravitational pull towards hegemony, and the ubiquity of some hegemonial authority in societies of independent or quasi-independent states, stands out so clearly from the evidence that the question arises why studies of states systems and political theory underestimate or even ignore it. (...) Our vision is constricted by the assumption that the independent sovereign state is the basic or even the sole unit of a states system" (Watson, 1992: 314; cf. Kagan, 1998!).
\end{abstract}

Watson går så vidt i sin internationale samfundsoptik som til at tale om det nedarvede præg af kontrakt (Watson, 1992: 318). Watsons fortolkning af verdenshistorien blev modtaget med superlativer som mesterlig i sit opgør med nutids- og anarkifikseringen inden for faget international politik. Nogle finder dog den engelske skoles tavshed om eksempelvis Ruslands kvaler med at blive en del af det europæiske internationale samfund problematisk (Neumann, 1996). Rent stilistisk spøger det indforståede og det uhåndgribelige - det er ikke just en begynderbog. Men den er en imponerende kombination af empirisk og analytisk overblik - ikke nær så omfangsrig, som man kunne frygte.

\title{
Buzans og Littles verdenshistorie
}

Der er mere politologisk murstensroman over Buzan og Little (2000) som følge af forfatternes socialisering ind i neorealismen (strukturrealismen, som de kalder den, cf. Buzan, Jones og Little, 1993). Bogens koncept fylder over en fjerdedel, og den empiriske verdenshistorie omfatter ikke alene antikken og moderniteten samt lidt nutid og fremtid, men sågar også forhistorien samtidig med, at forfatterne holder fast i international politiks kernebegreb, det internationale system, som omdrejningspunkt. Ligesom Watson (1992) er det en syntese af faglitteraturen, ikke historisk grundforskning, men Buzan og Little påtager sig her en totalentreprise: logikken i kollektiv menneskelig interaktion helt tilbage fra jæger/samler-samfundene. Denne utrolige ambition indfrier bogen faktisk, så hvor Watson blev rost til skyerne, kappede anmelderne selv jordforbindelsen i deres hyldest af denne bog. Det siger sig selv, at der males med bred pensel, og gennemgående er det en ret uskøn prosa - ræsonnementer vedrørende enheder (: det enkelte politiske system), interaktionskapacitet, proces/procesformationer samt struktur inklusive sondringen mellem funktionel og strukturel differentiering. Alligevel har de studenter, som jeg har undervist $\mathrm{i}$ verdenshistorie og international politik, taget Buzan og Little (2000) til sig. De to yder en stor pædagogisk indsats ved at rubricere og konkretisere, hvad der politologisk set er væsentligt at forstå om forløbet og dynamikken i verdenshistorien. 
Buzan og Little stopper imidlertid ikke ved den didaktiske ambition ("in a sense it is a textbook", 2000: 1). Forfatternes virkelige ærinde er at gøre begrebet det internationale system til omdrejningspunkt for al samfundsvidenskab såsom antropologi, geografi, statskundskab, ja selv historie - vel at mærke det internationale system frigjort fra den aldeles ahistoriske, eurocentriske, "anarkofile" og følgelig misvisende omgang med begrebet, man ser inden for faget international politik (2000: 18-34). Hermed siger forfatterne endegyldigt farvel til neorealismen og tilslutter sig den engelske skoles nuancerede "treenighedslære" som ovenfor omtalt (2000: 43-47). Samtidig vedgår de, at den engelske skole overser international politisk $\emptyset$ konomi, fordi den er optaget af det immaterielle institutionelle spil mellem aktørerne. De deler neorealismens tro på stringens og systematik, og selv konstruktivismen er med. De store forventninger, de herved rejser til empirisk og faglig alsidighed, indfrier de ved at opdele den internationale politik i fem, ikke indbyrdes afsondrede sagområder: militar, politik, фkonomi, samfund og miljø, som kan optræde på fem mulige analyseniveauer: system, subsystem, enhed, subenhed (indenrigsniveau) og individniveau - niveauer, som forfatterne bruger for at komme frem til deres pointer på det aggregerede, verdensomspændende systemniveau.

Denne 25-feltstabel (!) for, hvor de henlægger deres empiriske analyse undervejs, kobler forfatterne til deres forklaringsfaktorer eller rettere kilder til forklaring - henholdsvis interaktionskapacitet, proces og struktur, hvoraf navnlig procesanalysen systematisk ser på sagområderne. Proces skal nemlig forstås som den faktiske interaktion mellem aktørerne, hvorimod interaktionskapacitet henviser til potentialet for interaktion på et givet tidspunkt af verdenshistorien. Interaktionskapacitet drejer sig om store gennembrud inden for transportteknologien (stigbøjlen, bringeselen, jernbanen osv.) eller åndssfæren, eksempelvis skriften, diplomatiet, verdensreligionerne og de verdslige ideologier (Buzan og Little, 2000: 8084). Buzan og Little vedgår frejdigt deres gald til de gamle, delvis berygtede geopolitikere med deres sans for mobilitet og topografi (2000: 57-60). Enheds- og strukturbegreberne er kendte fra neorealismen, men bruges langt mere alsidigt her sådan, at den suveræne stat og anarkiet får en anderledes beskeden plads.

Hvad angår nøglebegrebet, det internationale system, er forfatterne på det rene med, at det er lidt absurd at krænge det ned over forhistoriens delvis førsproglige, for slet ikke at tale om førstatslige virkelighed. Men på basis af den arkæologiske forskning og vor viden fra nutidige "lommer" af forhistorisk kultur insisterer Buzan og Little på, at interaktionen mellem forskellige jæger/samler-grupper (huntergatherer bands) udgør prae-internationale systemer. I det mindste udgør forhistorien det kronologiske og udviklingsmæssige forspil til den gradvise fremvækst af landsbyer, byer og dermed oldtidens bystater og imperier. Derfor kan samfundsforskere ikke ignorere forhistoriens samfund, deres mulige organisering og udadvendte dynamik. Heller ikke hvad antikken angår, er det uproblematisk at tale om internationale systemer på grund af den begrænsede interaktionskapacitet. Man kan højst tale om фkonomiske internationale systemer ud fra den samhandel, man kan påvise mellem oldtidens civilisationer og imperier - typisk kun i en lineær og ikke en multilateral struktur. I det fjerde århundrede f.Kr. - under Athens storhedstid 
- havde Rom megen kontakt med såvel karthagenienserne (fønikeme) og de græske bystater, men ikke med Perserriget længere mod øst; det havde primært de græske bystater (Buzan og Little, 2000: 99). Det moderne, nutidige og vitterlig verdensomspændende internationale system, foreslår Buzan og Little derfor at kalde fuldbyrdede internationale systemer (2000: 96). Begrebet forudsætter, at interaktionen omfatter alle sagområder og analyseniveauer på verdensplan, men ikke nødvendigvis i en symmetrisk fordeling fra det enkelte geografiske område til det andet.

Som man kan ane, er Buzan og Little enige med meget af den etablerede historiske og makrosociologiske forskning og dens grundlæggende periodisering af verdenshistorien (Buzan og Little, 2000: 394, 386ff.). De opererer kun med tre, ret velkendte udviklingsafsnit: forhistoriens præ-internationale systemer fra 40.000 år f.Kr. frem til sumereme, antikkens gensidigt forbundne (økonomiske) internationale systemer fra 3.500 f.Kr. til 1500 e.Kr. og endelig modemitetens globale internationale system fra 1500 e.Kr. og frem. Ikke overraskende kommer der mest strukturhistorie og uendelig lidt begivenhedshistorie ud af den kronologiske ramme, heriblandt en sjusket omtale af bogtrykkerkunstens revolution (cf. 2000: $286 \mathrm{og}$ 203). Ellers vrimler det med spændende betragtninger inklusive illustrative cases i grå bokse. Modsat Thomas Hobbes' skrækvision hedder det om forhistorien:

"There has never been a presocial Hobbesian world of human beings in which life was just nasty, brutish, and short. We know that human beings have always lived in society, because they evolved from primates which are now all recognized to be innately social beings" (Buzan og Little, 2000: 111; cf. Poulsen, 2004).

Det betyder ikke, at sikkerhedsproblemer, trusler og krig var ukendte i forhistoriens univers. Faktisk var drabsraten ("krigshyppigheden") blandt buskmændene i Kalahari-ørkenen fire gange højere end i USA i årene 1920-1955 (Buzan og Little, 2000:129-130).

Kritikken af neorealismen går blandt andet på, at det ikke er forandringer på struktumiveau, men forandringer indadtil i enhederne, der skaber de største transformationer op gennem verdenshistorien (Buzan og Little, 2000: 374f., 7). Hvem kunne for eksempel i Middelalderen forudsige, at den tids vakkelvome kongedømmer få århundreder senere ville ende som verdensbetvingende imperiale centre? Følgelig må analysen foldes ud og bringes væk fra neorealismens misvisende fokus på polaritet, dvs. antallet af stormagter i den globale magtbalance (2000: 384). Waltz' arrogance med hensyn til økonomi gør neorealismen yderligere anakronistisk, fordi det $\emptyset$ konomiske sagområde altid ligger milevidt forude for det militær-politiske i sin dynamik (2000: 385). Denne og de $\emptyset$ vrige seks teoretiske hovedkonklusioner ser Buzan og Little som en

\footnotetext{
"damning indictment of much IR [=international relations/MS] theory. [...] [L]inking IR and world history is not just a marginal luxury that IR theorists can take or leave as they wish. It is an essential act, without which IR theory can never hope to capture its subject. [...] [W]ithout the link to world history, IR will never [...] develop its role as the integrating macrodiscipline of the social sciences" (Buzan og Little, 2000: 385).
} 
På det punkt har de ikke alverden til overs for postpositivismen, altså det, jeg her benævner den sproglige drejning (cf. note 2). Nok kritiserer postpositivisterne neorealismen, men de bidrager ikke til analysen af verdenshistorien på faget international politiks grundlag (Buzan og Little, 2000: 391). Som før antydet, er det en anklage, jeg kan tilslutte mig, og som uddybes som konklusion.

\section{Paul Kennedys verdenshistorie}

$\mathrm{Nu}$ kunne man tro, at neorealismen hermed var ude af billedet som ramme for politologisk analyse af verdenshistorien, men sådan er det ikke. Ganske vist må man gøre det kunstgreb at se bort fra Waltz (1979) og rette blikket mod Robert Gilpin (1981) og hans anderledes dynamiske neorealisme samt den "verdenshistorie", der ligger i forlængelse af ham - Kennedy (1988) med andre ord. Såvel Buzan og Little som Watson omtaler Gilpin og Kennedy i respektfulde vendinger (Watson, 1992: 9; Buzan og Little, 2000: 53). Først lidt om Gilpins principielle syn på drivkræfteme bag den makropolitiske udvikling og parallellen til Kennedy, da han ikke just går i dybden med sit koncept - man er vel historiker! Gilpins neorealisme viser sig i hans konkurrenceoptik på international politik samt hans materialisme, hvor magt bliver et spørgsmål om militær, økonomisk og teknologisk formåen (Gilpin, 1981: 13). Modsat Waltz (1979) låser han sig ikke fast på staten som aktør og dermed den westfalske epoke, men henviser til både Pax Romana og Napoleon som udtryk for den hegemoniske logik bag historiens omskiftelighed. Med andre ord relativiserer Gilpin anarkitesens gyldighed og godtager indirekte Wights tese om verdenshistorien som en serie af hegemoniske tilstande (cf. Watson, 1992: 3f.). Det karakteristiske for Gilpin er hans dynamiske, halvvejs marxistiske materialisme, hvor nøglebegrebet er de uens takter for militær, $\varnothing$ konomisk og teknologisk vækst stormagteme imellem (Gilpin, 1981: 12ff.). Den ulige vakst skaber ubalance og krise i det internationale system, da Gilpin forudsætter interessekonflikter mellem hegemonen og dens forstødte og nye rivaler. Dramatiske forskydninger i magtfordelingen vil bringe hegemonen til fald og skabe et nyt internationalt system. Altså en neorealisme, der stiller skarpt på forandring, men fastholder Waltz' pointe om, at aktøreme ser på deres relative gevinster i den indbyrdes konkurrence. Samtidig er Gilpin i pagt med Buzan og Little i sin betoning af, at forandringer i international politik hidrører fra enhedemes indre dynamik.

Kennedys (1988: xv) argument er tilsvarende bygget op omkring ulige vækstrater og udviklingen $i$ den relative magtfordeling mellem stormagter og stormagtsaspiranter: "how a Great Power's position steadily alters in peacetime is as important to this study as how it fights in wartime". Hans omfangsrige empiriske klassiker om udviklingen fra 1500 e.Kr. undersøger derfor samspillet mellem økonomisk formåen, samfundets bredere ressourcer og den militære effekt, det udmøntes på slagmarken i den direkte konfrontation mellem stormagteme. Kennedy er berømt for sin tese om imperial overbelastning (imperial overstretch):

"... wealth is usually needed to underpin military power, and military power is usually needed to acquire and protect wealth. If, however, too large a proportion of the state's resources is 
diverted from wealth creation and allocated instead to military purposes, then that is likely to lead to a weakening of national power over the longer term. In the same way, if a state overtextends itself strategically - by, say, the conquest of extensive territories or the waging of costly wars - it runs the risk that the potential benefits from external expansion may be outweighed by the great expense of it all - a dilemma which becomes acute if the nation concerned has entered a period of relative economic decline" (Kennedy, 1988: xvi).

Den betragtning gjorde Kennedys bog til en af de mest omdiskuterede i den intense debat om USA's nedgang i årene lige før opløsningen af Sovjetunionen, hvor man bagefter med stor lettelse konkluderede, at Kennedy tog fejl - USA's position var alligevel ikke truet. Man overså ganske, hvor tesen om imperial overbelastning holdt stik, nemlig som forklaring på, hvorfor Sovjetunionen tabte den kolde krig (cf. Kennedy, 1988: 488-514). Kennedy tog kun fejl ved at forudsige, at Sovjetunionen ikke ville give op før den havde lidt nederlag i en varm krig, sådan som mønstret har været for andre hegemoner. Bogens normative budskab er således, at hegemonisk status forudsætter en balanceret og dynamisk politik på hjemmefronten og en fordomsfri analyse af de til enhver tid gældende internationale vilkår for magt samt politisk vilje til at omsætte indsigten i handling. Det er dårligt nyt for denne verdens lukkede samfund og autoritære politiske systemer; en pointe, Kennedy desværre undlader at præcisere. Hans forkærlighed for komparativ statistik om stålproduktion og andre militære nøgletal skræmmer nok nogle læsere bort. Men reelt er han næppe uenig med neoliberale magtanalytikere som Joseph S. Nye (1988), der helt parallelt betoner behovet for at balancere mellem hard power (militærmagt mv.) og soft power (at være et politisk-kulturelt forbillede, præstere velfærdsformåen og have legitime institutioner osv.).

Som verdenshistorier betragtet er der en perfekt arbejdsdeling mellem Kennedy (1988) og Watson (1992). Hvor Watson helliger sig det immaterielle spil mellem aktørerne - "overbygningen" fristes man til at sige med Karl MarX - kulegraver Kennedy storpolitikkens materielle basis hen over de sidste 500 års omskiftelige strategiske spil mellem stormagterne. Kennedy er blevet kritiseret for ikke at inddrage indenrigspolitiske faktorer som social og fysisk mobilitet, herunder indvandring, et område hvor USA står stærkt. Trods bogens mangler lufter Kennedy dog visse nuancer og slår ned på kvalitative tiltag som de selvkritiske evalueringer af nederlag i Preussens generalstab (Kennedy, 1988: 185). Han erkender, at passive faktorer som landes geografiske beliggenhed og afsondring har spillet ind. Han lægger ikke skjul på analysens eurocentri og begrunder det med, at det langvarige fravær af stærke kontinentaleuropæiske hegemoner fra Roms fald og frem gav Europa ideelle betingelser - modsat situationen i Kina og andre steder - for en dynamisk, teknologisk betinget militær kappestrid mellem de fremvoksende autonome politiske systemer. Herved blev Europa arena for de globalt set afgørende hegemoniske opgør. Først USA føjede en ny dimension til.

Kennedys periodisering af hans udsnit af verdenshistorien følger materialismens princip og gør industrialiseringen til krumtap. Overordnet skelner han mellem den førindustrielle verdens strategi og økonomi (fra "det europæiske mirakel" o. 1500 til 1815, hvor industrialiseringen endnu ikke var slået igennem i Europa som helhed), den fuldbyrdede industrialiserings tidsalder (1815-1943, dvs. fra den euro- 
pæiske koncert til slaget ved Stalingrad) og endelig strategi og фkonomi i dag og $i$ morgen (1943-2000). Den essentielle neorealisme hos Kennedy er de relative gevinsters forrang, der ligger som præmis for hele analysen, et udslag af hans konfliktoptik. Det levner ikke plads til megen samfundsoptik, ej heller systemræson. Her kan den engelske skole med rette indvende, at der kommer noget tautologisk ud af at definere problemstillingen som eksistenskampe mellem autonome politiske systemer. De har i verdenshistorisk perspektiv udgjort et provinsielt modernitetsanliggende. Men det faktum, at de har været skæbnesvangre for verden som helhed og er udgangspunktet for nutiden og fremtiden, gør dem unægtelig mindre ligegyldige, og som nævnt $i$ indledningen giver globaliseringen og USA's nuværende rolle i international politik stof til en ny runde i debatten om hegemoni.

\section{Danske populærvidenskabelige bidrag til den historiske vending}

Selv om der er et spring i stil og akademisk ambition fra de omtalte verdenshistorier inden for faget international politiks litterære kanon til det danske bogmarkeds tilsvarende udgivelser, er de alligevel relevante som lokale udslag af den historiske drejning. Det gælder Dansk Udenrigspolitiks Historie 1-6 (Due-Nielsen, Feldbæk og Petersen, 2001-2005). Værket henviser ikke til den engelske skoles grundsyn på udenrigspolitikkens vilkår, men den engelske skoles alsidighed (dens "treenighedslære") er indirekte til stede. Pointen i Bo Lidegaards kontroversielle analyse af Erik Scavenius i bind 4 er netop denne statsmands placering i et voldsomt dilemma mellem flere uforenelige, men alle for så vidt legitime hensyn. Hvor han valgte at prioritere den kortsigtede statsræson, slog modstandsbevægelsen under besættelsen på den langsigtede systemræson og krævede, at Danmark bidrog til at bekæmpe den totalitære trussel mod verdensordenen og menneskeheden. Dilemmaer er der også mange af i Danmarks EU-politik og var det givetvis også bagud i historien, som for eksempel da Christian d. 4. spillede højt spil i Trediveårskrigen. Hertil kommer hele værkets underliggende hovedtema om Danmarks egen transformation som aktør op gennem historien, en dynamik, der hovedsagelig er betinget af den omgivende internationale politiks skiftende vilkår (se Nikolaj Petersens artikel i dette nummer). Siden vikingetiden har Danmark gennemløbet hele spektret i Watsons (1992) kontinuum over politiske systemers autonomi og er i dag en småstat, om end en småstat i kategorien stærke stater.

Skal man fremhæve en enkelt nulevende dansk analytiker, der indgående har beskæftiget sig med hele verdenshistorien og reflekteret over den i populariseret form, må det blive Erling Bjøl. I sin disputats (Bjøl, 1966: 14, 16) tilsluttede han sig C.A.W. Mannings og dermed den engelske skoles synspunkt, at det plausible snarere end videnskabelige love er, hvad politologer kan præstere. På det grundlag har han arbejdet meget med overordnede mekanismer i historie og international politik. Som hovedredakt $\varnothing \mathrm{r}$ af Politikens Verdenshistorie 1-21 valgte han at indlede værket med et meget rost essay om hovedlinjer i historien (Bjøl, 1982). Her anslog han adskillige af de tværgående temaer og pointer, som man ellers skal til Buzan og Little (2000) for at finde samlet. Når Bjøl udfolder sig om bringeseler, stigbøjler, " $k \varnothing l$ og hjul" osv. er det tydeligvis den forbedrede interaktionskapacitet i fortidens samfund, som det handler om. Meget sigende indleder han med skriften 
og behandler sidenhen de sociale teknologier for interaktionskapacitet - organisation, verdensreligioner og videnskab (Bjøl, 1982). Under overskriften "Kræfter og bedrifter" afrunder han med samfundsvidenskabernes fælles aktør/strukturproblematik og drager en balanceret konklusion (Bjøl, 1982: 326-328).

Dette livtag med verdenshistorien førte til endnu to monografier med sikkerhedspolitikken som omdrejningspunkt - hans “Krig og Fred" kan man sige (Bjøl, 1998; 2000). Krigsmonografien stiller spørgsmålet om kriges generelle årsager og begynder med aktør/struktur-problemet. Som svar på de vanskeligheder, konfliktforskningen rummer, anbefaler han, at faget international politik tager den diakrone komparation (se note 3), altså den empiriske verdenshistorie til sig:

\begin{abstract}
"Hvis man kan iagttage de samme træk i beslutningssituationer, som ligger fjernt fra hinanden i tid og sted, må det sandsynliggøre, at der er tale om noget karakteristisk for afgørelser, der fører til krig eller fred. Hvis man f.eks. kan påvise fællestræk mellem Bismarcks og dronning Margretes politik eller i Frederik d. 3.s og Saddam Husseins beslutninger, eller i de hensyn, der indgik i Margaret Thatchers og Perikles' overvejelser. Om 'den tilstrækkelige lighed' er til stede, afhænger af abstraktionsniveauet" (Bjøl, 1998: 16).
\end{abstract}

Selv om Bjøl her afslører, at han hælder mod aktømiveauet, som det, der typisk rummer den udslaggivende faktor, går han ind på strukturelle forhold som geografi, teknologiske gennembrud efterfulgt af mere voluntaristiske momenter som nationalisme, ekspansionisme, magtbalance og ikke-militære formål med krigsførelse samt utilsigtede krige ("lavinekrige"), noget første verdenskrig er et gruopvækkende eksempel på. Men beslutningssituationen får det sidste ord i slutkapitlet af samme navn, som i realiteten betoner faktorer som misperception (cf. Jervis, 1976). Man kan indvende, at Bjøl her og bogen igennem underspiller sine ræsonnementer til fordel for den livlige, tematiserede beretning ud fra historiens arsenal af krige og krigsskabende hændelser. Resultatet er imidlertid et tankevækkende konfliktanalytisk executive summary af verdenshistorien og som sådan en stor populærvidenskabelig bedrift.

Fredsmonografien (Bjøl, 2000) fungerer på samme måde med de samme fortrin og svagheder. Bogen opererer med to idealtypiske institutionelle rammer for fred, rigsfreden og ligevægtsfreden, dvs. fred gennem hegemoni over for fred gennem magtbalance mellem autonome politiske systemer. Rigsfreden hører især fortiden til, så denne del af bogen drejer sig om Romerriget og dets Pax Romana, samlingen af Kina som "den himmelske freds rige" og de mere skibbrudne fors $\emptyset \mathrm{g}$ på at skabe en Guds fred i Middelalderens Europa via kristenhedens republik. Bjøl ser paralleller til rigsfreden i det sikkerhedsfællesskab, der er skabt mellem demokratierne i Vesteuropa og nu udstrakt til Østeuropa (Bjøl, 2000: 312, 328). Ligevægtsfreden kommer til udtryk i de spilleregler og den magtbalance som gradvis voksede frem mellem de europæiske stater fra religionskrigene i 1500-tallet frem til den kolde krig og vel også videre at dømme efter den centrale balancerende rolle i Golfområdet, som Saddam Hussein blev tillagt. Hvad den kolde krig angår, siger Bjøl meget forfriskende, at USA lige fra starten praktiserede flexible response og aldrig andet over for den sovjetiske trussel; den gode nyhed var nemlig, at de sovjetiske ledere lod sig afskrække. Omvendt viste det sig fatalt, da man på et 
falsk grundlag fors $\emptyset$ gte at praktisere ligevægtsfred med Hitler gennem appeasement kan man tilføje.

Både her og med hensyn til de andre fredsmekanismer - såsom kræmmere og kvinder - der drøftes, er det svært at udlede noget virkelig almengyldigt, blandt andet fordi krig og fred er langt mere relative fænomener, end man skulle tro, hvilket giver lidt overlapning mellem diskussionerne i de to monografier. Med tanke på nutidens netværksagtige aktører som $\mathrm{Al}$ Qaeda og en diffus, men grum verdensomspændende konflikt mellem islamisme og modernitet og hele nutidens generelle mønster af intrastatslige konflikter kan Bjøls overvejende interstatslige statsmandsunivers selvfølgelig forekomme bedaget. Men hverken de dårskaber eller de optioner, han peger på, er nødvendigvis irrelevante for fremtidens sikkerhedspolitik. Selv om også fredsmonografien i passager fortaber sig i bred kronologisk beretning, tilgiver jeg gerne Bjøl. For herigennem bliver det klart, at det, der fascinerer ham ved historien, er den samme politologiske ordens-, dynamik- og organisationsproblematik, som optager Watson (1992) og Buzan og Little (2000). Påny ræsonnerer han snublende nær op ad Buzan og Littles begreb interaktionskapacitet:

"Politisk, men især kulturelt var integrationsniveauet usædvanlig højt i Europa mellem 1713 og 1792. Kommunikationskapaciteten mellem de politiske og kulturelle eliter var høj. Evnen til at opfatte de nuancer, som ifølge Napoleon kunne gøre forskellen mellem krig og fred, var vel udviklet. De politiske systemer var vel forskellige (...). Men enhver regeringsform kunne være god nok, når bare det var duelige 'Regentere', som var ved magten. Samkvemmet mellem eliteme var ubesværet. De havde et fælles omgangssprog i fransk" (Bjøl, 2000: 156-157).

\section{KonkJusion}

Den historiske drejning går ud på at fjerne det ahistoriske præg, som behavioralismen har påført studiet af international politik og har i den mere ambitiøse udgave til formål herved at gøre faget international politik til det holistiske omdrejningspunkt for samfundsvidenskaberne. Det typiske teoretiske afsæt er den engelske skoles pluralistiske tilgang til international politik, men visse dynamiske varianter af neorealismen gør sig også gældende. Konkret består den historiske drejning i den nye underskov af politologiske synteser af verdenshistoriens empiriske stof, dvs. analyser af logikken bag de forskelligartede politiske systemers opståen, deres indbyrdes samkvem, konflikthåndtering og udvikling op gennem historien. I praksis er der faktisk ikke tale om historisk grundforskning, kun om en nyvakt interesse for (litteraturen om) de førindustrielle epoker og de politologiske følgeslutninger, man kan udlede af deres praksis. Men fordi den historiske drejning således står og falder med historikernes udforskning af den type problemstillinger, bør sluresultatet blive et mere balanceret og indbyrdes respektfuldt forhold mellem statskundskab og historie. Set med statskundskabens øjne er der al mulig grund til at byde en sådan udvikling velkommen som en chance for at bryde med den fremherskende sproglige drejnings skævvridning af samfundsvidenskaben.

For som det indirekte fremgår af Buzan og Littles (2000: 391) undsigelse af postpositivismen som irrelevant for bestræbelsen på at gøre international politik til den dagsordensættende samfundsfaglige disciplin, dækker den sproglige drej- 
ning over en uholdbar metodisk ensidighed. Den anskuer virkeligheden som konstruktioner, fortællinger/diskurser - altså som "tekster" med den praktiske konsekvens, at datagrundlaget for dens samfundsforskning reduceres til tekster af forskellig beskaffenhed. Diskursanalyse bliver eneste anvendte metode, typisk med afsæt i åbne, publicerede kilder, publicistik eller sekundærlitteratur om identitet osv., hvorimod arkivalier og i det hele taget data i bredere forstand samt metodisk alsidighed glimrer ved sit fravær. Det er en hård anklage, men at der er noget om snakken finder jeg bekræftet $i$, at nogle fortalere for den sproglige drejning selv erkender, at tekstanalyser af intemational politik ofte bliver ren lænestolsforskning (armchair analysis; Neumann, 2002: 628). I forhold til det er klassisk historisk forskning en oase af flid og alsidighed (cf. Clausen, 1963) - så alsidig faktisk, at man kan hævde, at historiefaget via hermeneutikken for længst har taget højde for mange af den sproglige drejnings indsigter. Det samme må gælde for netop den historieinspirerede engelske skole og strengt taget også for de mere tænksomme udgaver af neorealisme og neoliberalisme.

\section{Noter}

1. Idiografisk betyder fokus på de individuelle, særegne træk ved det fænomen, der studeres, og er det stikord, historievidenskaben selv har taget til sig som karakteristik af faget. Det tyske fagudtryk Einmaligkeit bruges på samme måde. Modsætningen hertil er nomotetisk, dvs. orienteret mod at finde lovmæssigheder og almene trak. Parallelt med det tillægges historievidenskaben en slagside i retning af at forklare fænomener alene gennem forståelse og indlevelse, hvorimod politologi lægger vægt på at forklare kausalt og objektivt $i$ betydningen set udefra. Max Weber anså forståelse for uvidenskabelig og forklaring som et umuligt ideal for samfundsvidenskab og konkluderede, at samfundsforskere må kombinere dem. Se i øvrigt H.P. Clausen (1963) som giver en god indføring i historisk videnskabsteori - mere nuanceret og tidssvarende end den egentlige guru på området, E.H. Car (1960).

2. Den sproglige drejning henviser til den sprogvidenskabeligt inspirerede diskursanalyse, dvs. de seneste årtiers tekstanalytiske modebølge inden for international politik og samfundsvidenskaberne mere bredt, inklusive historie. Den er synonym med postmodernisme, socialkonstruktivisme, postpositivisme og lignende - altså strømninger, som mere eller mindre radikalt afviser, at der findes en objektivt eksisterende virkelighed og i stedet ser på konstruktionen af virkeligheden gennem sproglige og andre virkemidler. Se i øvrigt Smith, 1997.

3. Diakron analyse indebærer, at fænomener analyseres $i$ et historisk perspektiv, typisk med vægten på fænomenernes oprindelse, udvikling og eventuelle ophør. Det modsatte princip kaldes synkron analyse og går ud på, at man fastfryser tidsfaktoren og i stedet lader den rumlige dimension variere ved at studere beslægtede fænomener andre steder. Begge principper er gyldige strategier for komparation, men politologer har det med kun at tænke i synkron komparation studiet af flere samtidige cases.

4. Udtrykket "den engelske skole" bruges i det følgende ikke fordi det er en præcis og geografisk set holdbar tenn for retningen - tværtimod! - men fordi det kendes af mange. Indholdet i den engelske skole præsenteres senere.

5. Behavioralismen var, som navnet antyder, rettet mod at studere adfærd, ikke tankeprocesserne bag eller andre ikke-iagttagelige fænomener. Ligesom positivismen opfatter den sin metode som værdineutral og objektiv, studiet af "fakta" slet og ret.

6. Hermeneutik, dvs. fortolkningslære går ud på at leve sig ind i personen bag handlingen eller udsagnet for at få rede på den pågældendes forudsætninger, normer, hensigter og vidensgrundlag og er følgelig en integreret del af kildekritikken, historieforskningens kernemetode (cf. Clausen, 1963: 31, 62, 90-94). 
7. Den meget nuancerede neorealist Robert Jervis (1982) deler Watsons begejstring for den europæiske koncert som noget så enestående som en sikkerhedspolitisk regimedannelse, men understreger, at koncerten kulminerede i tiden frem til 1823. Under alle omstændigheder var koncerten ophævet under Krimkrigen (1853-56).

\section{Litteratur}

Bjøl, Erling (1966). La France devant l'Europe. La politique europeenne de la IVe Republique, København: Munksgaard.

Bjøl, Erling (1982). Politikens verdenshistorie bd. I: Fra Urtid til Nutid, København: Politikens Forlag.

Bjøl, Erling (1998). Hvorfor krig?, København: Gyldendal.

Bjøl, Erling (2000). Hvordan fred?, København: Gyldendal.

Bull, Hedley (1969). "International Theory: The Case for a Classical Approach", in Klaus Knorr and James N. Rosenau (eds.), Contending Approaches to International Politics, Princeton: Princeton University Press.

Bull, Hedley (1977). The Anarchical Society. A Study of Order in World Politics, London: Macmillan.

Buzan, Barry, Charles Jones and Richard Little (1993). The Logic of Anarchy: Neorealism to Structural Realism, New York: Columbia University Press.

Buzan, Barry and Richard Little (2000). International Systems in World History. Remaking the Study of International Relations, Oxford: Oxford University Press.

Carr, Edward Hallett (1960). What is History?, New York: Vintage Books.

Clausen, Hans Peter (1963). Hvad er Historie? Den historiske videnskabs metodiske grundspørgsmål og nyere synspunkter på historieforskningens teoretiske problemer, København: Berlingske Forlag.

Cox, Michael, Timothy Dunne and Ken Booth (eds.) (2001). Empires, Systems and States. Great Transformations in International Politics, Cambridge: Cambridge University Press.

Due-Nielsen, Carsten, Ole Feldbæk og Nikolaj Petersen (red.) (2001-2005). Dansk Udenrigspolitiks Historie 1-6, København: Danmarks Nationalleksikon.

FN, Danmark og verden (1999), København: DUPI.

Gilpin, Robert (1981). War and Change in International Politics, Cambridge: Cambridge University Press.

Hardt, Michael og Antonio Negri (2004). Imperiet, København: Informations Forlag.

Jackson, Robert (1995). “The Political Theory of International Society", pp. 110-128 i Ken Booth and Steve Smith (eds.), Intermational Relations Today, University Park: Pennsylvania State University Press.

Jackson, Robert and Georg Sørensen (1999). Introduction to International Relations, Oxford: Oxford University Press.

Jervis, Robert (1976). Perception and Misperception in Intermational Politics, Princeton, NJ: Princeton University Press.

Jervis, Robert (1982). “Security regimes", International Organization, Vol. 36, No. 2, pp. 357-378.

Johnson, Chalmers (2004). The Sorrows of Empire. Militarism, Secrecy and the End of the Republic, New York: Metropolitan Books.

Kagan, Robert (1998). "The Benevolent Empire", Foreign Policy, No. 111, pp. 24-35.

Kennedy, Paul (1988). The Rise and Fall of the Great Powers: Economic Change and Military Conflict from 1500 to 2000, London: Unwin \& Hyman.

Knudsen, Tonny B. (1999). Humanitarian Intervention and International Society. Contemporary Manifestations of an Explosive Doctrine, $\mathrm{PhD}$ dissertation, Århus: Department of Political Science, University of Aarhus.

Knutsen, Torbjørn L. (1997). A history of international relations theory, 2nd ed., Manchester and New York: Manchester University Press. 
Lal, Deepak (2004). In Praise of Empires. Globalization and Order, Houndsmill, Basingstoke: Palgrave Macmillan.

Mann, Michael (1986). The Sources of Social Power. Vol. 1: A History of Power from the Beginning to $A D$ 1760, Cambridge: Cambridge University Press.

Mann, Michael (1993). The Sources of Social Power. Vol. 2: The Rise of Classes and Nation-States 1760-1914, Cambridge: Cambridge University Press.

Moore, Barrington Jr. (1966). The Social Origin of Dictatorships and Democracy. Lord and Peasant in the Modern World, Boston: Beacon Press.

Neumann, Iver B. (1996). Russia and the Idea of Europe: A Study in Identity and International Relations, London: Routledge.

Neumann, Iver B. (2002). "Returning Practice to the Linguistic Turn: The Case of Diplomacy", Millenium: Journal of International Studies, Vol. 31, No. 3, pp. 627-651.

Nye, Joseph S. (1988). Bound to Lead. The Changing Nature of American Power, New York: Basic Books.

Osiander, Andreas (1994). The States System of Europe, 1640-1990. Peacemaking and the Conditions of International Stability, Oxford: Oxford University Press.

Poulsen, Jørgen J. (2004). “Zoon Politikon. Om statskundskabens grundlag”, Politik, 7. årgang, nr. 3, pp. 96-109.

Rasmussen, Erik (1968). Komparativ Politik 1, København: Gyldendal.

Skak, Mette (2000). "Back in the U.S.S.R.? Russia as an Actor in World Politics", København: DUPI Working Paper, No. 7.

Smith, Steve (1997). "New Approaches to International Theory", pp. 165-190 in John Baylis and Steve Smith (eds.), The Globalization of World Politics. An Introduction to International Relations, Oxford: Oxford University Press.

Tilly, Charles (1992). Coercion, Capital and European States, AD 990-1990, rev. pbk. ed., Cambridge, MA: Blackwell Publishers.

Waltz, Kenneth N. (1979). Theory of International Politics, New York: McGraw-Hill, Reading; Addison-Wesley.

Watson, Adam (1992). The Evolution of International Society. A Comparative Historical Analysis, London \& New York: Routledge.

Wivel, Anders (2002). “Realismen efter Waltz: udvikling eller afvikling?”, Politica, 34. årgang, nr. 4, pp. 431-448.

Wolfers, Arnold (1962). Discord and Collaboration. Essays on International Politics, Baltimore: The Johns Hopkins University Press. 